\title{
THE FUTILITY OF THE ANGLICAN CHANT
}

\author{
By CHARLES WILLIAM PEARCE
}

W

ORDS which have to be sung, demand special fitness of musical setting from the rhythmical point of view. Not only should there be complete coincidence between musical and verbal accentuation; but the self-evident principle should always be borne in mind that prose, having no regularly recurring accent, can never be set with good effect to strictly metrical music which is only capable of suitable association with metrical poetry. It is the vain attempt to effect such an inartistic mesalliance which constitutes the futility of the Anglican chant.

The history of music presents no anomaly more curious than this; so that a brief investigation of the causes which produced it cannot fail to be as interesting to the general music-lover as to the church musician. It may be described as a case in which a certain musical device originally designed for the collective recitation of a number of literary couplets in distich form, admirably suited as it was at the time of its invention for the purpose which called it into existence, became after a time not merely unsuitable for that purpose, but actually perversive of good effect. And, more strangely still, this same musical device under its altered conditions -having become popular on its own account-is still largely used, in spite of its unsuitability for its original purpose.

The principle of fitness in a musical setting derives additional force for its practical application, when the words to be sung are of the highest interest and importance to everyone concerned in their recitation. It cannot be denied that of all the "books" of the Old Testament Scriptures, the Psalter stands out preeminently as a collection of sacred songs conveying a message to men "not of an age, but for all time." It has been well said that "the very excellence of the Psalms is their universality. Springing from the deepest fountains of the human heart, they are an everlasting heritage to mankind." The words of the Psalter deserve therefore a sympathetic rendering, in which any attempt at their musical setting must neither fetter the freedom of their rhythm, nor obscure their meaning.

Hebrew poetry, as exemplified in the Jewish Psalter, is in distich or couplet form, with a rhythm unfettered by laws of 
prosody. An essential feature of this ancient oriental poetry is the regular balancing and adjustment of its ideas and sentiments by the use of parallelism. The latter portion of each distich, couplet, or psalm-verse is, therefore, a more or less amplification, modification, answer, or completion of the former portion; and this essential feature is clearly traceable where the original Hebrew poetry is translated into what may be termed the "poetical prose" of some other language. Thus, in both Latin and English translations of the Psalter, the distich or couplet form of each verse is observable in the two portions separated by the dividing colon. Of these two portions, the latter forms a confirmation or extension of the sentiment conveyed by the former:-

Lotatus sum in hic, qua dicta sunt mihi : in domum Domini ibimus.

I was glad when they said unto me : we will go into the house of the Lord.

Amplius lava me ab iniquitate mea : et a peccato meo munda me.

Wash me throughly from my wickedness : and cleanse me from my sin.

Ne projicias me a facie tua : et spiritum sanctum ne auferas a me.

Cast me not away from Thy Presence : and take not Thy Holy Spirit from me.

Benigne fac Domine in bona voluntate tua Sion : ut adificentur muri Jerusalem.

$O$ be favourable and gracious unto Sion : build Thou the walls of Jerusalem.

There is abundant evidence to prove that not only in the Temple at Jerusalem but in the synagogues of the Jewish Dispersion, every care was taken by the "chief musicians" or those in musical authority, that whenever a Psalm was sung in Hebrew public worship-whether to a "cantillation" or elaborate solosetting by some trained singer, or to a simple massive chant voiced by a great congregation-any music so used should be fitted to the words in the manner best suited to their rendering by the vocal means available.

Congregational-rather than solo-recitation of the Psalter was a distinctive feature of early Christian worship. Naturally, the first step in the history of collective Psalter-recitation would be the saying of the words by each individual member of the community or congregation in his or her ordinary conversational voice: something entirely different to the singing worship of the persecutors whether Jewish or Roman. The next step, as a deliverance from such an inevitable vocal chaos, would be the introduction of a monotonic recitation i.e. the adoption of some note 
of fixed pitch upon which both men and women could recite collectively, with an octave or some other concordant interval between them:-

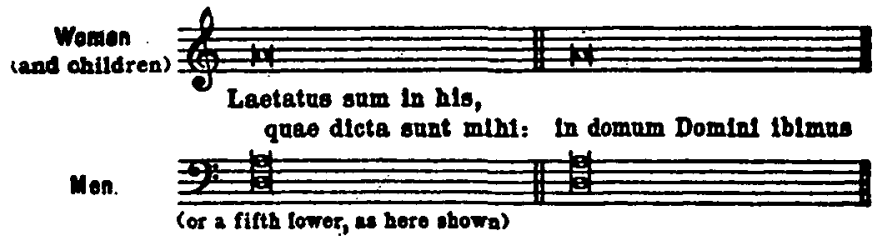

The melodic structure of a "Gregorian" Psalm "Tone" of early date conveys the strongest possible suggestion-if not actual evidenceof such a system of monotonic recitation having been tried and improved upon, because apparently it did not meet the necessities of community or congregational recitation. Reading between the lines, it can easily be seen that the love of variety, the craving for melody however simple, the desire not to unduly wear out the voice by continually singing upon only one note, led to the "inflection" of the monotonic recitation as a necessary vocal relief. Such inflection was easily obtained by causing the voice at the middle and end of every psalm-verse to wander away from the monotone to some adjacent scale-degree:-

The early Christian Choint-form

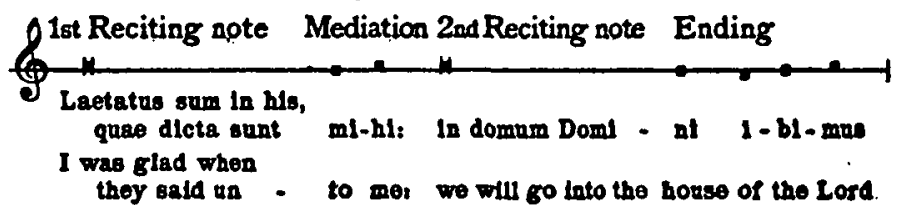

Thus arose the Gregorian Tone or Chant, a melodic formula in which the two reciting-notes of the same pitch are apparently the remains of an earlier and invariable monotonic recitation. The Ambrosian Tones or Chants of the fourth century had inflected endings, but monotonic mediations. As a rule, the Gregorian half-verse inflection (mediation) was shorter than the whole-verse inflection (ending). This rule, be it observed, still governs the making of any new Anglican chant at the present day. It may be remarked here, that for practical purposes, inflections were as necessary for an efficient choral ensemble as they were for individual vocal relief. A few experiments with a choir will speedily demonstrate the truth of this. It can also be seen from Figure 2 how rhythmically elastic are both the mediation and ending of a 
Gregorian Tone. There are no fixed accents in the music. In the Latin version of Psalm CXXII, verse 1, given in Figure 2, the verbal accents fall thus:-

1st Reciting-note-on the 3rd syllable from the end.

Mediation - on the first syllable thereof.

2nd Reciting-note-on the second syllable from the end.

Ending-on the second syllable thereof.

In the English Version they fall thus:-

1st Reciting-note-on the second syllable from the end. Mediation - on the second syllable thereof.

and Reciting-note-on the 4th syllable from the end. Ending-on the first and 4th syllables thereof.

Yet, the same smooth and simple melody suits the totally different accentuation of the words of the two versions equally well. Moreover, the melody itself gains constant rhythmical variety by the continual shifting of the accent from one note to another: a variety which is maintained all through even the longest Psalm sung in either version; for in the free rhythm of prose the succession of accented and unaccented notes is not as fixed and regular as in the strict rhythm of poetry.

It may be observed also that in the English Version of the Psalter generally, the accent by no means falls on the final syllable of either mediation or ending as it does in theEnglish words of Figure 2. Mr. John Heywood in his Art of Chanting (1893) states that a complete tabulation of the verse-endings of the Prayer-book Version of the English Psalter-made by him on the simple basis of good reading-shows 86 verses with the last accent on the fourth syllable from the end, 35 verses on the fifth, 7 on the sixth, and in one verse as far back as the seventh syllable from the end. Very nearly as many verses have the accent on the penultimate as upon the ultimate syllable; and about a quarter of that number have the ante-penultimate syllable accented.

This tabulation is quite sufficient to show that the continual shifting of accent from one syllable to another in the endings of Psalm-verses needs great rhythmical freedom and elasticity in any musical setting to which it is intended to sing every verse of a Psalm. The melodic structure of the Gregorian Tone fully meets the rhythmical needs of every Psalm verse in a perfectly ideal way.

With the introduction of vocal harmony into the worship of the Church, the Chant underwent great changes. It was first discovered that the inflected monotone-the Canto fermo or "fixed 
song" of the Chant-gained enormously in its ensemble effect by being accompanied by some other melody (or melodies) sung simultaneously with it. If the previous use of merely unaccompanied melody afforded relief to voices wearied by monotone, the introduction of harmony yielded contrast and delight not only to the singers, but to those who took their part in Divine Service by meditative listening only. With the gradual introduction of choral harmony came the following degradation of the chant from its first and high estate. Originally the Canto fermo was sung by the tenors, while other "inflected monotones" were sung by the other voices according to the rules of Strict Counterpoint:-

Christ-Church Tune (1664)

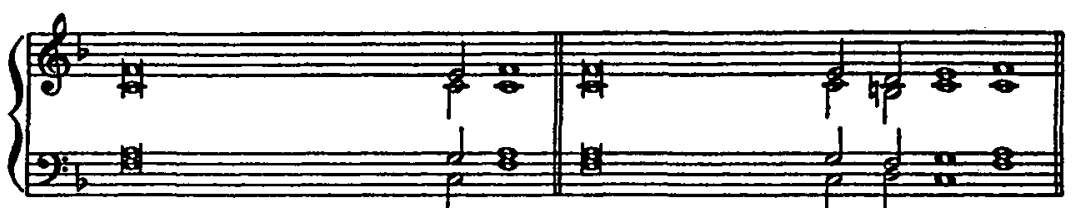

I was glad when they said un-to me: We will go into the house of the Lord.

But, finding that the Canto fermo did not attract sufficient attention when sung by the tenors, and that congregations-especially the female portions thereof-regarded and sang the added treble part as though it were the principal melody of the chant [exactly as they do now-a-days, and always will do, with Tallis's "Festal Responses"] the next step was to transfer the Canto fermo from the tenor to the top-part:-

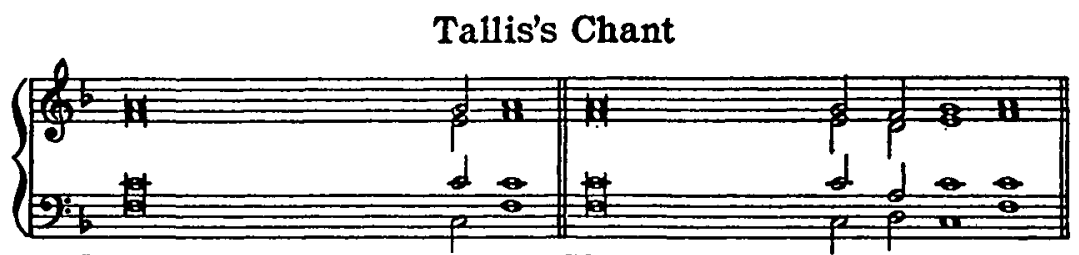

I was glad when they sald un-to me: We will go into the house of the Lord

With the invention of the "perfect cadence" came the realization of the rhythmical fact that the final tonic chord which concluded any composition carried with it the final strong accent of the music. It was the practical application of this principle which completed the evolution of the Anglican chant as we know it, by the insertion of bars. These were introduced in order not only to mark the accent, but to facilitate the keeping together of the four parts of the choral harmony. The Anglican chant then began 
to settle down into its present crystallized form of an eight-bar sentence, of which the first bar is missing:-

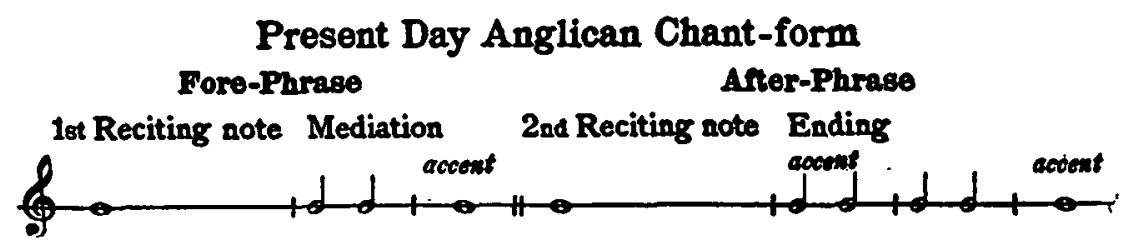

The strong accent on the final semibreve of the after-phrase-that representing the tonic chord of the perfect cadence-soon became a convenient vehicle for carrying strongly accented syllables which fall some distance away from the end of the psalm-verse. This system of "pointing"-as it is called-brought about such rhythmical subdivisions of the final bar as:-

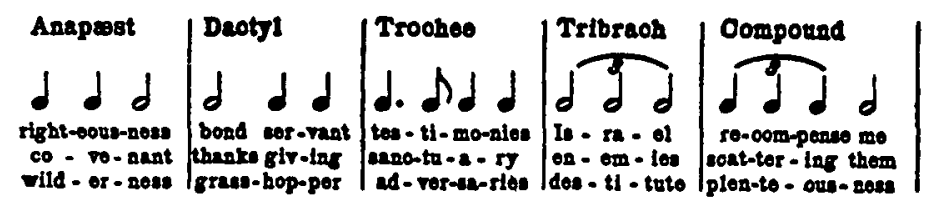

This rather frequent rhythmical subdivision of the final semibreve of the Anglican Chant has-not unjustly-been severely dubbed by various writers as "clatter, jingle, postman's double-knock, unmelodious huddling, thump, sledge-hammer accentuation." One reason why such a pointing system should be considered bad, lies in the fact that it produces a mongrel chant-form with three reciting notes; one at the beginning, another at the middle, and a third at the end! This third "reciting-note" by abolishing the chant-like prolongation of the final verbal "foot," brings about loss of dignity as well as the lack of a sense of finality and repose. But, worst of all, it closes a psalm-verse with a series of rhythmical jabberings unknown in any other phase of musical art. What would be said of a song-composer who ended a sentence thus:-

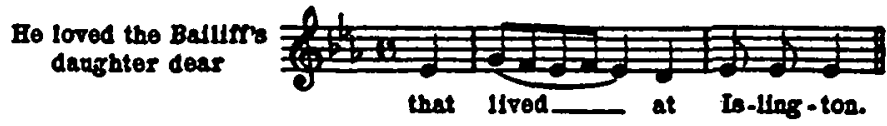

We all know the explanation of Beethoven's jabbering ending of the Allegretto scherzando movement in his Eighth Symphony:-

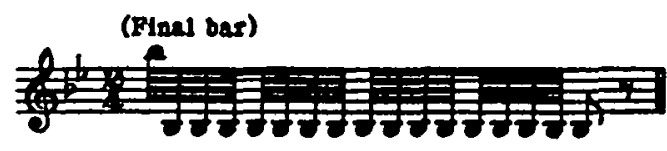


It is only fair to say, however, that the comparatively modern introduction of this final jabbering recitation at the end of so many Psalm-verses caused a split in the camp of Anglican Psaltereditors. One side- of which Monk and Ouseley were the chiefs -made the initial recitations of each half-verse as long as possible, by securing as much purely syllabic pointing as they could for the mediation and ending. The other side-represented by the "Cathedral Psalter". Editors-made the initial recitations as short as possible. This shortening process was effected not only by crowding as many syllables as possible into the last bar of each chant-phrase, but by separating-by what they termed an "imaginary bar" - the initial semibreve of each phrase (or its rhythmical subdivision) from the beginning of the recitation, thus:-

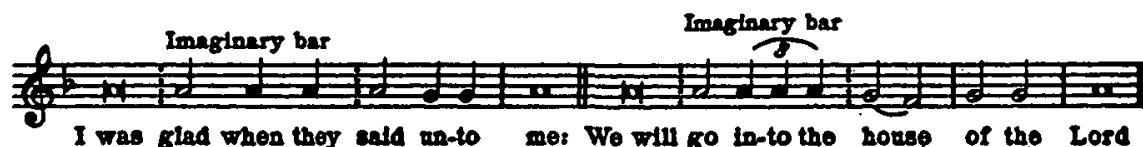

This "imaginary bar" shown between the dotted lines in Figure 8, is in pointed psalters of the "Cathedral" type indicated either by a short bar-line, or by printing in distinctive type the first syllable contained within its limits:-

I was GLAD when they | said unto | me: We will GO into the $\mid$ house $\mid$ of the $\mid$ Lord.

Dr. E. J. Hopkins in his Temple Psalter pursued this idea to its utmost limits by practically "barring" out the entire recitation:

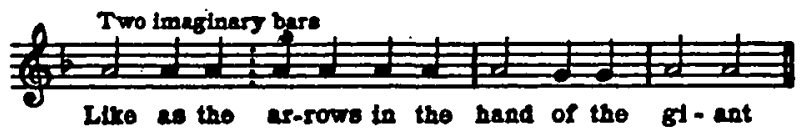

Rhythmical subdivision of the minims in the mediation and ending of a chant-which were fairly general in the 18th century-are even now to be met with. Here is the first portion of a wellknown double-chant which appears in Sir George C. Martin's New Cathedral Psalter Chants (1909):-

J. Battlabill

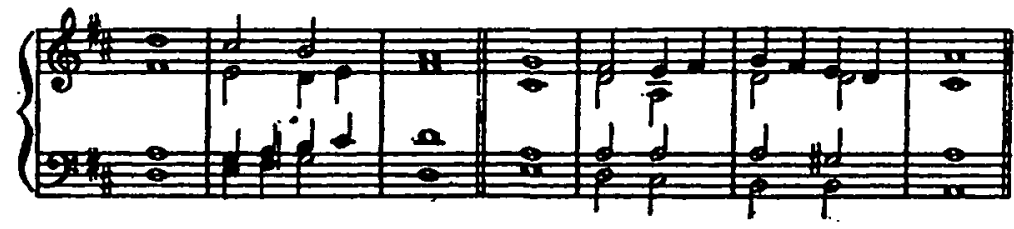


Thus, by degrees, the Anglican Chant, from being originally nothing but a mere faux bourdon harmonization of a Gregorian Tone set as a Canto fermo in the tenor part, became a complete selfcontained musical sentence of one invariable "cut-and-dried" shape, with a fixed unbending rhythm only capable of being fitted with any degree of musical propriety to poetry with regularly recurring binary feet. Its melody became jerky and unecclesiastical in character, often proceeding by wide leaps, and not infrequently by other unvocal intervals; its harmony became chromatic and increasingly dissonant, even upon the semibreves assigned to the recitations. And, by such means the chant became more and more unsuitable for constant and mechanical repetition to a long succession of psalm-verses containing frequent changes of rhythm and sentiment, and widely different phases of religious thought and feeling.

It is difficult to realize how such an anomalous incongruity as that of singing English prose with a perfectly free rhythm to a constantly repeated musical sentence in strict and unvaried metre could ever have arisen, and have been persisted in for more than two centuries. The strongest advocates of this system would scarcely tolerate the mesalliance of Shakespearian blankverse with an Anglican chant:-

Mornington's Chant

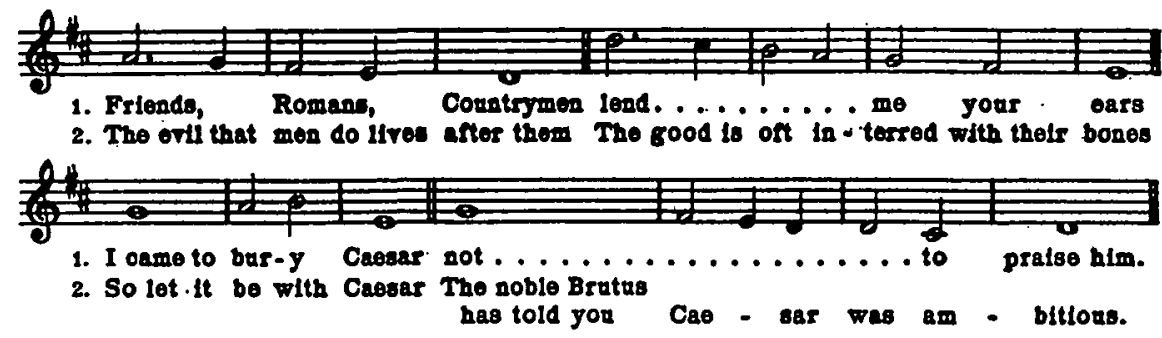

Such a mesalliance can only suggest possibilities of a comic-opera or a music-hall "turn"; indeed it is a marvel that it has escaped this ridicule for so long. When the time comes for such an exposure, if it ever does, church musicians will realize how much they have been blinded by tradition. But, up till the present time, the preface to every pointed Psalter makes it clear that the Anglican Chant is so popular on its own account, and may be considered to be so perfect a little art-creation in itself, and so unalterable in its fixed rhythm, that the only way of getting the Psalms sung to it, is to make the sacred words fit the stiff 
unbending metrical music as neatly as possible-regardless of the inevitable consequences of so illogical a proceeding.

Why is the Anglican Chant mésalliance still so widely accepted? is a question sometimes asked, but very seldom answered. The only possible explanation of such a paradox is the well-known fact that familiarity with a system often leads to unquestioned adherence to its principles, however wrong these may be. The apparently unaccountable toleration of Anglican pointing and chanting by clergy and organists may be accounted for when it is remembered that such people have lived under these conditions all their lives. They have assumed them to becorrect, but they have never deemed it necessary to search for any grounds for such an extraordinary belief. It has been humorously said that anything can be popularized from a frill to a psalter-pointing; but extensive usage, by even a big majority, by no means predicates the intrinsic value of the thing used. It is only when organists and clergy vacate their places in the choir, and become ordinary members of the congregation in the nave and aisles, that they begin to realize the enormous incongruity, stupidity, and even wickedness of employing the Anglican Chant as a musical setting of the English prose Psalter. Then, the question arises:-how can we sing so strange a song in the Lord's land? And to such a question there ought properly to be only one answer, and that a decisive one in the direction of the complete abolition of an abuse which has disfigured the choral service of the Anglican Church for two centuries and more. 